\title{
Public Management and Disaster Risk Reduction: potential interdisciplinary contributions
}

\section{Gerrit van der Waldt}

School for Social and Government Studies

North-West University

Potchefstroom

gerrit.vanderwaldt@nwu.ac.za

\section{ABSTRACT}

This article investigates the interdisciplinary nature of Disaster Risk Reduction as an emerging field of study. The development of this field of study is interpreted within the context of the evolution of Public Management as an academic discipline. The author argues that the philosophical and theoretical underpinnings of both Public Management and Disaster Risk Reduction share commonalities. Thus, the foundational and functional aspects of Public Management did, and should continue to, inform and enrich the study of Disaster Risk Reduction.

\section{KEYWORDS}

Public Management, Disaster Risk Reduction, academic discipline

\section{Orientation}

'No man is an island, entire of itself...' This quotation from John Donne (15721631) puts forth an essential idea, which is representative of the multidisciplinary nature of the study of phenomena, namely the idea that people are not isolated from one another, but that humankind and related phenomena are interconnected.

To obtain holistic perspectives phenomena should be studied from various vantage points, such as their social and cultural dimensions, economic implications, political dynamics, technological challenges, and so forth. From a Systems Theory perspective and by following a comprehensive approach, it could be argued that applied disciplines, such as Disaster Risk Reduction (DRR), should con- 
stantly adjust, rediscover and enrich themselves by 'borrowing' useful theories, approaches, methodology, principles and concepts from established, related disciplines. This of course does not preclude scholars in the field from developing new, unique theories and methodologies. It could furthermore be argued that the very survival of applied disciplines is dependent on the degree to which they succeed in adjusting and applying themselves to changing macro conditions and circumstances ('usefulness') or they may run the danger of becoming impoverished and ultimately even obsolete. In this regard Van der Waldt and Du Toit (1999:62) argue that overlapping and interaction with other disciplines are essential and that the exchange of influences is important.

Over time any discipline moves through various maturity levels to become an entrenched science. Public Management as a discipline emerged from Political Science as a distinct discipline during the 1880s and went through various maturity levels or paradigmatic stages. The work of theorists such as Gulick (1937), Simon (1946), Rowat (1961), and Caiden (1991) contributed significantly to establish Public Administration as a science. DRR can be regarded as an emerging, distinct study domain that originated from various disciplines such as Environmental Studies and Public Management as mother disciplines as recently as the early 1990s. There seems to be relative consensus that Disaster Risk Reduction does not yet have a distinct and unique body of knowledge, methodology and theory to be typified as a 'discipline' (see Varley, 1994; Cardona, 1999; Luhmann, 1993). As such, scholars and practitioners in this emerging discipline should aggressively borrow, abstract, and apply theories, approaches, principles and best practices from related disciplines to obtain a more holistic perspective when exploring and analysing certain disaster and risk-related phenomena. In view of the proliferation of publications and legislation in the field, and the willingness of scholars to engage theorists from related disciplines, it could be argued that the maturity curve to be become a full-fledged discipline, is approaching at a rapid rate. Some protagonists in DRR argue that there is no need for it to become a discipline and that it should be 'mainstreamed' into related disciplines such as Public Management. The reality, however, is that tertiary institutions increasingly offer formal academic programmes in the field and that practitioners with job titles such as 'Disaster Managers' are established in Disaster Management Centres at municipalities. The promulgation of the Disaster Management Act 57 of 2002 in South Africa further necessitates a sound theoretical foundation from which policies, structures, systems, and programmes should be developed. A body of knowledge in DRR is thus required to make possible a logistical 
framework for the establishment of curricula to adequately capacitate practitioners in the field with knowledge and skills. This argument is supported by recent research undertaken by Stallings (2002:22-25) and Rodriguez, Quarantelli and Dynes (2006:55-56). 'Mainstreaming' into other disciplines will not happen by itself. Impetus for the development of DRR will only be provided by the establishment of a mature discipline.

From the arguments highlighted above the question arises: To what extent could Public Management on an interdisciplinary level make a meaningful contribution to enrich the study of Disaster Risk Reduction and to assist in the establishment of Disaster Risk Reduction as a mature discipline? It is the purpose of this article to explore the potential interface between these two study domains and to identify potential areas where Public Management could make contributions to obtain a fuller perspective on Disaster Risk Reduction within the South African context.

\section{Public Management as academic discipline}

The point of departure in any academic discipline is to reach consensus regarding a definition of the study domain. By analysing the definition, it is possible to demarcate basic concepts and explore the interdependencies regarding related concepts.

Governance, or the activity of tending to the needs of the population, through public management and governance, is as old as humankind itself. Aspects of the activities of government have been described by philosophers such as Socrates, Plato, and Cicero. From the earliest times people realised that by working together, they could reach their goals easier than by working individually; the goals being the delivery of services and products for the common good. They started off by working in small groups, then larger groups, and finally they established institutions to arrange and co-ordinate their activities.

Public Management (and/or Administration - depending on the approach followed) as an academic discipline is fairly new. The activity (practice) of public management and governance is, however, as old as humanity itself. As an academic subject, it originated in the United States of America in 1887 when Woodrow Wilson (28th president of the USA), wrote an article entitled "The study of administration". This article forms the basis of discussion and laid the foundation for the development of the subject. Wilson postulated that there is a difference between politics (the making of policy) and Public Management and Administration (the execution of policy), implying that the two could be separated. This idea 
resulted in a separation between Public Management and Administration and Political Sciences as disciplines. The discipline subsequently went through four broad paradigmatic phases and reached a stage where scholars could, broadly speaking, fall into one or more of the following five broad perspectives or approaches to the study of the discipline:

- The politics/administration dichotomy approach: Protagonists of this approach hold the idea that politics and public management and governance should be separated. Due to the close interrelationship between the making and the execution of policy, the opinion currently is that politics and public management cannot be separated and that we are faced with a politics/administration dichotomy. Public managers cannot function in a vacuum but have to take the functions and roles of their political heads into account.

- The conventional approach: According to this narrow approach (also called the functional approach), public management and governance is functionally restricted to clerical or administrative activities and refers to activities such as filing, office routine, invoicing, and general correspondence.

- The generic administrative approach: This approach view the so-called generic (from the French word "genre”, meaning 'family', 'class' or 'group') administrative process found in one public institution should also occur in all other institutions. This generic administrative process consists of the six generic functions, namely: policy-making; personnel administration; financing; organising; methods and procedures; and control.

- The business management approach: A tendency developed that if the efficiency of the public sector could be reduced to business principles, the principles of business management could be applied to the public sector in order to make the civil service equally efficient. Some exponents of Public Management do not share this view, as they are convinced that public management and governance is more comprehensive, dynamic and efficient than business management. They also believe that the business philosophies of market exploitation do not belong in the civil service, where the provision of service is of the utmost importance. What may well be used, are business techniques, that is, the application of instrumental aspects such as cost/utility analysis, efficiency analysis, cost-effectiveness and productivity analyses. 
- The comprehensive approach: Proponents of this approach see public management and governance as the total performance of functions by any civil servant. In its broadest sense, public management and governance can be defined as the activities of groups co-operating to accomplish common goals. A comprehensive approach therefore sees all work performed by the civil servant as part of public management and governance.

Public Management is characterised as an extremely broad field of study which hampers consensus regarding a comprehensive definition thereof. Irrespective of the particular approach there is, however, relative consensus that in any modern society the study of Public Management concerns the activities of the public service and what it does to tend to the needs of the population. The study of Public Management can therefore in very simple and holistic terms be described as the study of all the activities that are taking place in the public sector. In South Africa the public sector comprises the Public Service - all institutions and departments on national, provincial and local government levels, as well as the Police Service, National Defence Force, National Intelligence Agency, parastatals such as Eskom (electricity provider) and the South African Airways; and various nongovernmental organisations. The Public Service (e.g. state departments) is responsible for the implementation of public (government) policy and legislation (laws). The enabling activities of the Public Service are collectively known as public management and governance. Thus, in its broadest sense Public Management as science has to do with the study of 'government' (the structures and systems of Government) and 'governance' (the interaction between Government and civil society). Talbot (2001:270-271) identified interrelated elements of government, namely:

- Organisation (such as state departments, ministries, agencies, public enterprises and local government)

- Public resources (such as laws, money and employees)

- Programmes (such as health care, education and defence)

- Persuasion (covers information, statistics, research and communications).

- Rules (include the making of rules - promulgation, enforcing rules - penalties, and exemplifying compliance with rules).

If one makes a value assessment of the importance of effective public management and governance in any democratic society, it is important to critically examine the effects of good governance. It could be stated that without good governance (effective, efficient and economical public management) there will be 
serious consequences as far as a safe and healthy environment, the economy, infra-structural development, job creation, investment and general well-being, are concerned. In this regard the Constitution of the Republic of South Africa Act 108 of 1996 stipulates that public administration should adhere to a number of principles, including that:

- a high standard of professional ethics be promoted and maintained;

- services be provided impartially, fairly, equitably and without bias;

- resources be utilised efficiently, economically and effectively;

- peoples' needs be responded to;

- the public be encouraged to participate in policy-making; and

- it be accountable, transparent and development-oriented.

These principles will need to promote continuous improvements in the quantity, quality and equity of service provision. Any society is thus dependent on a wellfunctioning Public Service.

\section{Public Management: A Synopsis}

Below, a brief synopsis of some of the foundational aspects of Public Management is made. The purpose of this synopsis is to establish to what extent these aspects could be utilised within the domain of Disaster Risk Reduction.

- The collection of functions referring to the management functions of civil servants. These functions include policy-making and implementation, planning, financial management, methods and procedures, personnel management, organising, and control (Cloete, 1986).

- Performed by civil servants appointed and trained to perform work related to the delivery of service to the public at large (Thornhill and Hanekom, 1995:32-34).

- The locus - place where it occurs - is within the executive branch of government on national, provincial and local government levels. It thus refers to the bureaucracy (public institutions) charged with the formulation, implementation and evaluation of government policy (Hanekom, Rowland \& Bain, 1986).

- It occurs within a particular society as environment meaning that Public Management satisfies the needs of a specific society in a specific environment (Plumptre, 1991:30; Fox, Wissink and Schwella, 1991; Stoop and Grabe, 1993:24).

-To formulate, implement, evaluate and modify government policy referring 
to the inputs of civil servants in the creation of public policy and their role in implementing these policies to secure a reasonable safe and acceptable environment for all citizens of society (Van der Waldt and Du Toit, 1999:16).

The definitions highlighted above, provide some of the fundamentals of the subject. There are, however, peripheral aspects which are incorporated within the study domain. During the deliberations of the Standards Generating Body of Public Administration and Management (SGB:PAM) during 1998-2002, eleven functional areas of Public Management were identified. Based on the prescribed processes of the South African Qualifications Authority (SAQA), the purpose of the SGB was to develop unit standards per National Qualification Framework (NQF) level and identify outcomes per functional area associated with the discipline. The SGB comprise academics, practitioners, professional bodies, as well as members from specific specialisation areas. The functional areas which were identified are:

- Policy Analysis \& Management

-Development Management

- Public Organisational Development \& Management

- Managing public service delivery

- Human Resources Management

- Financial Management \& Procurement

- Information, Knowledge, Communication \& Technology Management

- Public Management Ethics

- Public Administration and Management history, theory and research

- Inter-Governmental Relations

- Disaster Studies

From this list three aspects should be highlighted: Firstly, the list is indicative of the broad, dynamic scope of the discipline; Secondly, Disaster Studies is seen as one of the functional areas of Public Management (not yet an independent, fullfledged discipline); and thirdly, each functional area has significant potential to enrich Disaster Risk Reduction as an emerging, applied science.

\section{Disaster Risk Reduction as an emerging science}

Although scholars such as Pringle (1942), Quarantelli (1954:267-275) and Moore (1956:734-737) made early attempts to develop a theory of disaster management, Jeggle (2001: 316) and Quarantelli (1998) are of the opinion that only during the past thirty to fourty years, there has been a continuous evolution in the common understanding of disaster management. The ISDR (2004:2) further 
highlights the fact that several powerful natural disasters during the 1990's and increased media attention, have provided impetus to the renewed focus on Disaster Risk Reduction. International response and aid became more prominent and visible.

A comprehensive definition is provided by the ISDR (2002:25) which defines disaster risk reduction as "the systematic development and application of policies, strategies and practices to minimise vulnerabilities and disaster risk throughout a society, to avoid (prevent) or to limit (mitigate and prepare) adverse impacts of hazards, within the broader context of sustainable development".

Westgate and O'Keefe (1976) attempted to highlight the complexities of disasters and their definitions, but, on a more fundamental level, Cuny (1983:3) maintains that natural disasters hurt people, and especially the poor. Wisner et al. (2003:3) concur, but add that the crucial point to understand why disasters occur is that it is not only natural events that cause them. They are also the product of the social, political, and economic environments, because of the way it structures the lives of different groups of people. Government, especially on local government level, is responsible for town, city and regional planning and could structure (place) society in such a way that would make people vulnerable to certain hazards. Government actions, or inactions, could thus significantly contribute to the exposure to risks and vulnerability of people. People, or mechanisms to ensure a safe environment for people (government; general well-being), are thus at the heart of the study domain. From the definitions of Public Management it is also clear that it has as locus and focus the well-being of society and the role of government in this regard. There is thus close correlation between the fundamentals of the two disciplines.

Figure 1 below depicts the contention that Public Management and Disaster Risk Reduction have both the same roots - foundational, philosophical underpinnings (A), namely the general well-being and common good of society. The specific focus of Disaster Risk Reduction within this foundation is to ensure a safe and healthy environment for people. From this foundational aspect, each study domain spirals outwards towards full maturity as a science. Public Management (C) is already well-established as a science, but, is it argued, that Disaster Risk Reduction is still enroute (B) towards maturity. Where the various maturity spirals merge cross-polination (borrowing, adopting, adjusting) of theories, principles, techniques, methodology, approaches, and so forth, occurs. It is further the contention that when a discipline reach full maturity it should continuously adjust 
and reinvent itself to remain in touch (useful) within a changing environment. New theories and hypothesis should constantly be developed and tested to further develop the discipline.

Figure 1: Outward spiraling towards maturity as a science

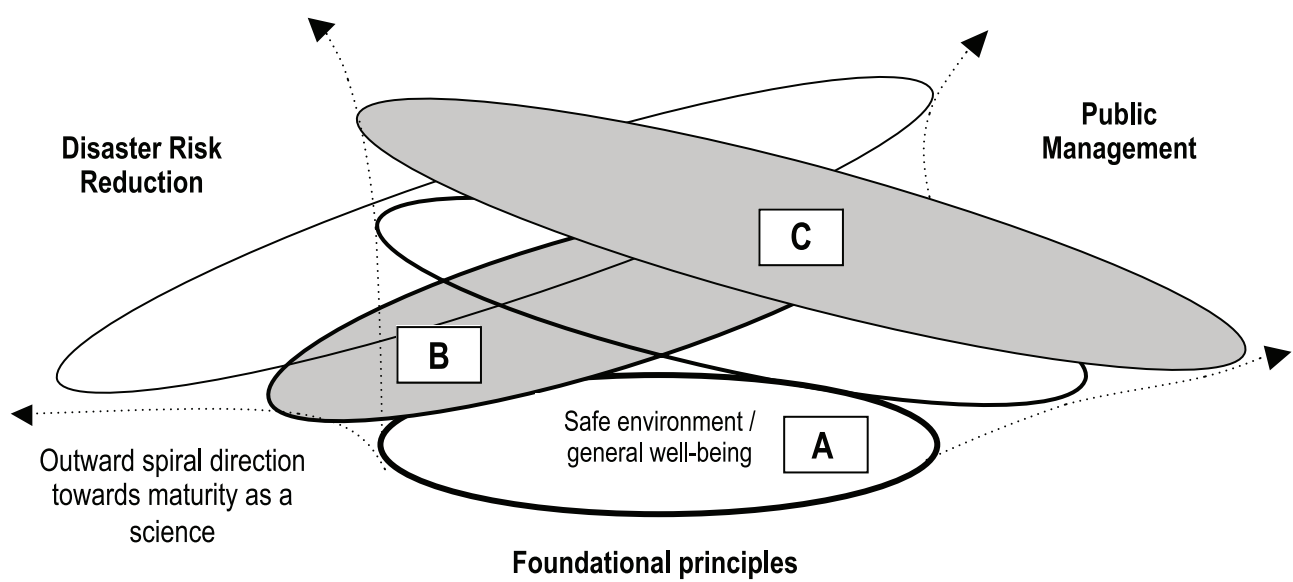

To facilitate the transition from one maturity level to the next, an emerging discipline should actively engage and interact with related disciplines to establish a body of knowledge appropriate for its study focus.

Fig. 2 illustrates how Disaster Risk Reduction should enrich itself by borrowing, adopting, adapting and entrenching appropriate theories, principles, tools, techniques and best practices from related disciplines such as Public Management, Engineering, Geography, Sociology and so forth. This will not only strengthen the study domain, but could eventually lead to new disaster-oriented focuses in the host disciplines. An example of this, is the fact that prior to 2000, no Disaster-related theories or principles were covered in any Public Management and Administration curricula at any university in South Africa. By placing aspects such as risks, vulnerabilities and disasters on the political agenda ultimately led to the promulgation of Disaster Management Act (57/2002), and since Public Management has to do with the execution of public policy, it led to the incorporation of the spirit and stipulations of the Act in main stream Public Management. 
Figure 2: Enrichment of Disaster Risk Reduction as a discipline

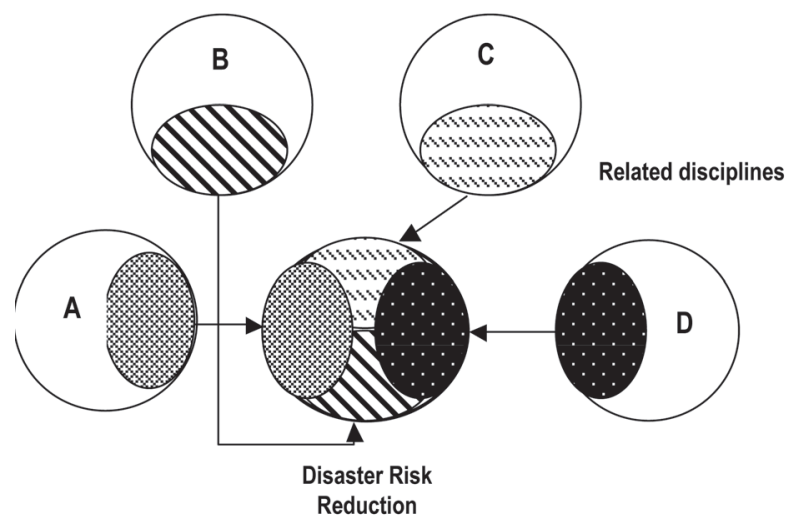

Although various discipline would offer various appropriate models, methodology, theories, principles, techniques, and so forth, it is argued that Public Management as foundational or root discipline could (and should) make a significant contribution to the establishment of a body of knowledge for Disaster Risk Reduction. Fig. 3 below illustrates how the two study domains should interact to provide a unique perspective when scholars in the field of Disaster Risk Reduction observe, study and analyse disaster and risk related phenomena.

Figure 3:Interdisciplinary contributions of Public Management

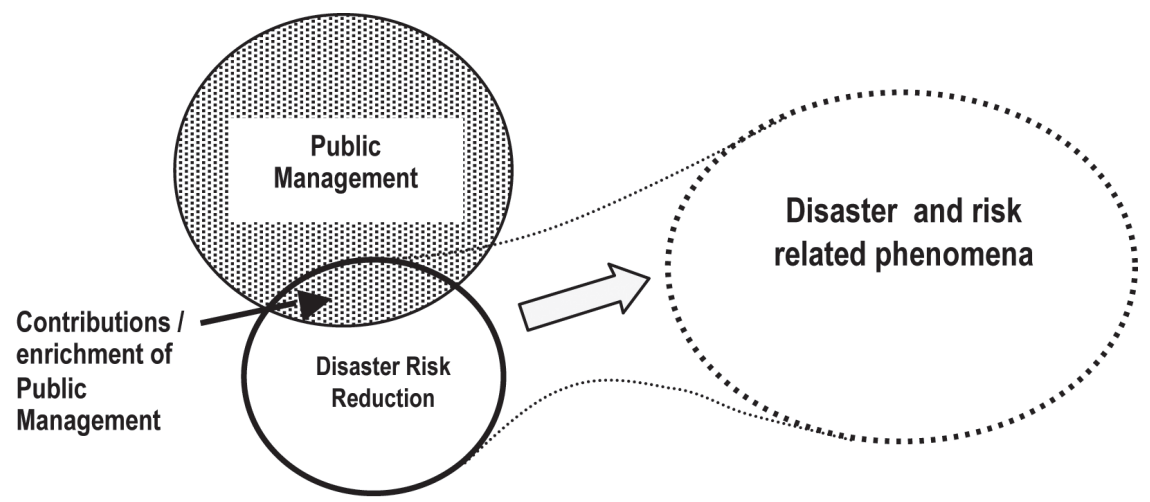




\section{Public Management and Disaster Risk Reduction: Interdisciplinary contributions}

It was argued that the root (philosophical underpinnings) of both Public Management and Disaster Risk Reduction is the same. There is thus close proximity between the more philosophical underpinnings of Public Management and Disaster Risk Reduction. Based on Figure 3 above (cross section 'A'), and from a more pragmatic perspective, the following specific contributions on both academic and practical (applied) levels could be made.

\section{Macro level contributions}

-The macro context/environment of Government and governance

- Political milieu

- Policy-making dynamics

- Developmental role of Government

- Structures and systems of Government

- Intergovernmental relations

- "Flattening" of organisational structures and globalisation pressures

\section{Meso level contributions}

- Policy analysis

- Organisational arrangements (departmentalisation, work procedures, etc.)

- Strategic planning and management

- Policy implementation strategies and mechanisms

- Utilisation of Information and Communication Technology

- Managing public service delivery through Programme and Project management

- Public-private partnerships and outsourcing

- Performance and quality management

- Public management ethics

- Fiscal arrangements, public financial management, budgeting and procurement

-Public human resource management

\section{Managerial (micro) level contributions}

-Technical and political advice to political heads (i.e. Ministers, MEC's, and councillors).

-Appropriate managerial skills, applications and techniques on strategic, tactical and operational levels.

- Management functions (e.g. planning, organising, leading, coordinating, etc.) 
- Policy implementing (e.g. setting goals and priorities, directing, coordinating and planning and evaluating of all facets of the policy implementation function).

- Resources management (e.g. the management of staff, finances, information, technology, supplies, accommodation and communication).

- Analytical and conceptual thinking.

\section{Conclusion}

From the above it is clear that Public Management as discipline could make a significant contribution to the study and practice of Disaster Risk Reduction. Any service provider of formal qualifications, and training and development programmes will be ill-advised not to include the foundational and functional aspects of Public Management in the curricula and syllabi of Disaster Risk Reduction and related foci.

\section{References}

CAIDEN, G.E. 1991. What really is public maladministration? Public Administration Review. Vol 51. November/December 1991. pp.486-493.

CARDONA, O.D. 1999. Environmental management and disaster prevention: Holistic risk assessment and management. In Ingleton, I. (ed) Natural Disaster Management. London: Tudor Rose.

CLOETE, J.J.N. 1986. Inleiding tot die Publieke Administrasie. Pretoria: Van Schaik.

CUNY, F.C. 1983. Disasters and Development. New York: Oxford University Press.

FOX, W., WISSINK, H. And SCHWELLA, E. 1991. Public Management. Kenwyn: Juta.

GULICK, L. 1937. Is Public Administration becoming a Science? In Gulick, L. \& Urwick, L. Papers on the Science of Administration. New York: Institute of Public Administration.

HANEKOM, S.X., ROWLAND, R.W. \& BAIN, E.G. 1986. Key Aspects of Public Administration. Johannesburg: Southern Book Publishers.

INTERNATIONAL STRATEGY FOR DISASTER REDUCTION (ISDR). 2002. Living with risk: A global review of disaster reduction initiatives. Preliminary version. Geneva: ISDR Secretariat.

INTERNATIONAL STRATEGY FOR DISASTER REDUCTION (ISDR). 2004. Living with Risk: A global view of disaster risk reduction initiatives. Volume 1. United Nations, New York.

JEGGLE, T. 2001. The Evolution of Disaster Reduction as an international strategy: 
Policy Implications for the future. In Rosenthal, U., Boin, R.A. \& Comfort, L.K. 2001. Managing Crises: Threats, Dilemmas, Opportunities. Illinois: Charles C Thomas Publishers.

LUHMANN, L. 1993. Risk: A Sociological Theory. New York: Aldine de Gruyter.

MOORE, H. 1956. Towards a theory of disaster. American Sociological Review. Vol 21. pp.734-737.

PLUMPTRE, T.W. 1991. Management in Government. 5th ed. The Institute for Research on Public Policy. Nova Scotia. pp.30-32.

PRINGLE, D.W. 1942. Civil Protection Services. May. Pretoria: The South African Treasurer.

QUARANTELLI, E.L. (Ed). 1998. What is a disaster?: Perspectives on the question. London:Routledge.

QUARANTELLI, E.L. 1954. The nature and conditions of panic. American Journal of Sociology. 60. pp187-194.

RODRÍGUEZ, H., QUARANTELLI, E.L. And DYNES, R.R. (Eds.) 2006. Handbook of Disaster Research. Texas: Springer.

ROWAT, D.C. 1961. Basic Issues in Public Administration. Toronto: Macmillan.

SIMON, H.A. 1946. The proverbs of Administration. Public Administration Review. Vol 6. Winter 1946. pp.58-61.

South Africa (Republic). 2003. Disaster Management Act No 57 of 2002. Pretoria: Government Printer.

South Africa (Republic). 1996. The Constitution of the Republic of south Africa Act 108 of 1996. Pretoria: Government Printer.

STALLINGS, R.A. (ed.) 2002. Methods of Disaster Research. USA: International Research Committee on Disasters Book Series.

STOOP, L.C.A. \& GRABE, J.J. 1993. Public sector productivity in the RSA: a case of decentralisation. Journal of Public Administration. Vol. 28, No. 1, Maart 1993. Pp.23-35.

TALBOT, C. 2001. Public performance: Towards a new model? In Van der Molen, K., Van Rooyen, A. \& Van Wyk, B. (eds) 2001. Outcomes-based Governance: Assessing the Results. Cape Town: Heinemann.

VAN DER WALDT, G. And DU TOIT, D.F.P. 1999. Managing for Excellence in the public sector. Kenwyn: Juta.

VAN NIEKERK, D. 2005. A Comprehensive Framework for multi-sphere Disaster Risk Reduction in South Africa. Unpublished $\mathrm{PhD}$ thesis. North-West University, Potchefstroom. 
VARLEY, A. (ed) 1994. Disasters, Development and Environment. New York: John Wiley and Sons.

WETGATE, K.N. And O'KEEFE, P. 1976. Some definitions of disasters. Bradford: Disaster Research Institute: University of Bradford.

WISNER, B., BLAIKIE, P., CANNON, T. And DAVIS, I. 2003. At risk: Natural hazards, people's vulnerability and disasters. 2nd ed. London: Routledge. 